\title{
Gender Inequality Causes and Impacts on Honor Killing: A Case Study of District Shikarpur, Sindh, Pakistan
}

\section{Pahor WA ${ }^{1}$, Guramani $\mathrm{AH}^{2}$ and Khan Pahore $\mathrm{D}^{3}$}

${ }^{1}$ Department of Soil Science, Shaheed Z.A Bhutto Agriculture College Dokri, Pakistan

${ }^{2}$ Department of Mass media and communication, University of Sindh, Jamshoro, Pakistan

${ }^{3}$ Department of Law, Shah Abdul Latif University, Khairpur, Pakistan

"Corresponding author: Pahor WA, Department of Soil Science, Shaheed Z.A Bhutto Agriculture College Dokri, Pakistan, Tel: 0744160470; E-mail: vicky2_pahore@yahoo.com

Received date: October 07, 2016; Accepted date: November 10, 2016; Published date: November 16, 2016

Copyright: @ 2016 Pahor WA, et al. This is an open-access article distributed under the terms of the Creative Commons Attribution License, which permits unrestricted use, distribution, and reproduction in any medium, provided the original author and source are credited.

\begin{abstract}
An attempt is made to find out the causes of gender inequality and its impacts on honor killing in district Shikarpur, Sindh, Pakistan in order to chalk out policies for protecting women from gender based violence particularly honor killing. Our research study revealed that gender inequality is one of the major problems in the study area that leads to honor killing of the women. Furthermore, our study revealed that illiteracy, forced marriages, male child preference and economic dependency of women over men are major contributing factors of gender inequality. Honor killing is also getting momentum with the passage of the time in the area. According to our research survey that 10 to 12 women are being killed annually in the name of honor killing and within 5 years, 45 women are penalized to death in the district and most of the honor killing cases are taking place in Lakhi town, followed by Garhi Yaisn town, Khanpur town and Shikarpur town respectively. Presently, a large number of measures are needed to be taken in terms of economic and social spheres in order to protect women from genocide in the area.
\end{abstract}

Keywords: Gender inequality; Genocide; Economic; Honor killing

\section{Introduction}

Gender inequality means unequal treatment with genders based on biological and physiological characteristics. Gender inequality may refer to superiority of man to his counterpart woman. This is way to consider woman inferior to man. Gender inequality is not justified by any society or law. Though, Pakistani educated civil society believes in it. Despite it is dominant social factor of Pakistani society particularly in backward areas of the country. Woman in Pakistan has no respectable place in society. Still, it is dominant believe that woman has been created only to serve man. As a result of this mind set, woman has socially harassed, politically undermined and economically pushed back. This is only central reason, why, woman has become unable to play constructive roles in the development of Pakistan. Currently, Pakistani woman is facing multifarious socio-economic and political confrontations that have greatly undermined her potential capabilities. Injustice against woman such as honor killing, acid throwing, domestic violence, harassment at public places and forced marriages are taking place throughout the country. Woman has no free access to get education, to earn for her livelihood, to participate in decision making process at domestic level, to own property, to decide her marriage and to do job. The Globe Gender Gap report 2013 published by World Economic Forum reveals that Pakistan is second worst country followed by Yemen in terms of gender equality and fair distribution of resources among man and woman. There is no doubt to say that without key participating of woman in socio-economic activities, the dream of greater Pakistan cannot be achieved. For sustainable development and progress of any country, woman's role is critical and essential factor similar with case of Pakistan (Figures 1 and 2).

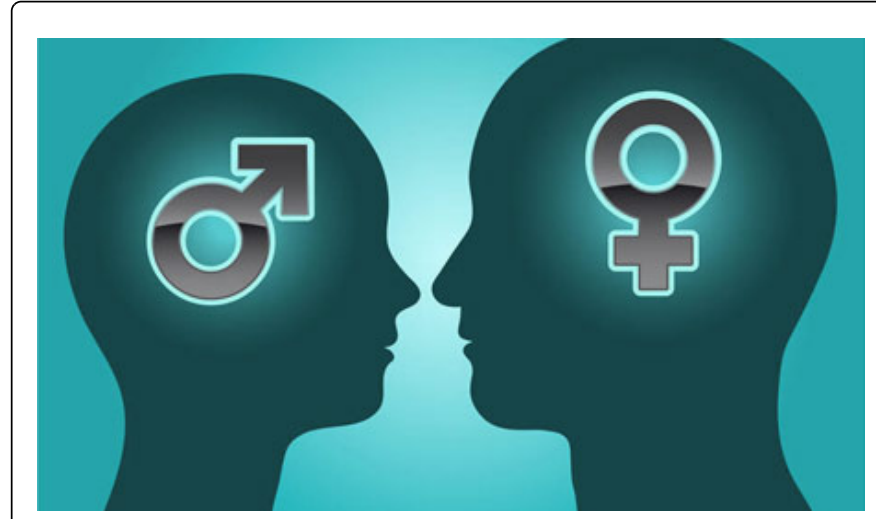

Figure 1: Taluka wise division of rural and urban population of Shikarpur.

\section{Honor killing a social injustice}

The so called honor killing is known as (Karo Kari) in Sindh Pakistan. It is a widespread heinous social crime against woman taking place at large scale. The word Karo is used for man and Kari is used for woman as described by local people. Honor killing is murdering of either man or woman found in adultery or inappropriate social relationship. In honor killing, accused couple is being killed on seeing or merely on rumor like sitting, mailing, seeing and walking. 
Page 2 of 4

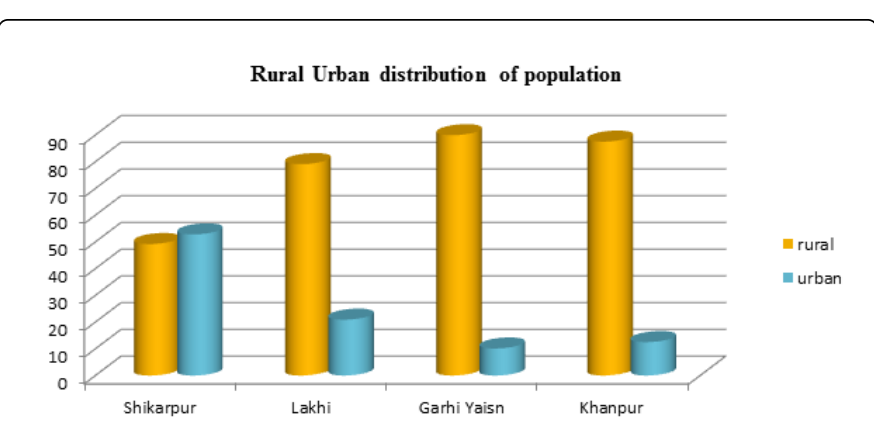

Figure 2: Population distribution in Rural and Urban.

Though, the life of both sexes is at risk but, in most cases woman is violated and killed. While, man escapes from death by paying money to family members of woman or using his social influence of tribal landlords. In Pakistan, honor killing has become a social norm. In 2011, human rights groups reported 720 honor killings in Pakistan
(605 women and 115 men). For instance Pakistan's Human Rights Commission reported that in 2010 there were 791 honor killings in the country, while Amnesty International cited 960 incidents of women alone who were slain in honor killings that year. While, according to, research survey done by Sindhi newspaper that 300 to 400 women are being killed annually in the name of honor killing in Sindh. If one looks deeply in this crisis, indeed, it seems a grave situation that needs to be addressed on prompt basis. So, we are in dire need to do something better for woman to protect her sanctity and her survival [1-3].

Like other part of Sindh province, since couple of years, honor killing has also been prevailing in district Shikarpur. Though, its pace is getting momentum now in district as tribal feuds get birth. In district, since back five years 45 women have been killed in the name of honor killing. Similarly, according to survey those 12 men have also been murdered in same incidents. While, most of the honor killing cases are taking place in Lakhi taulka followed by Garhi Yasin and Khanpur. In past five years 19 women and 6 men were penalized to death in Lakhi Taulka.

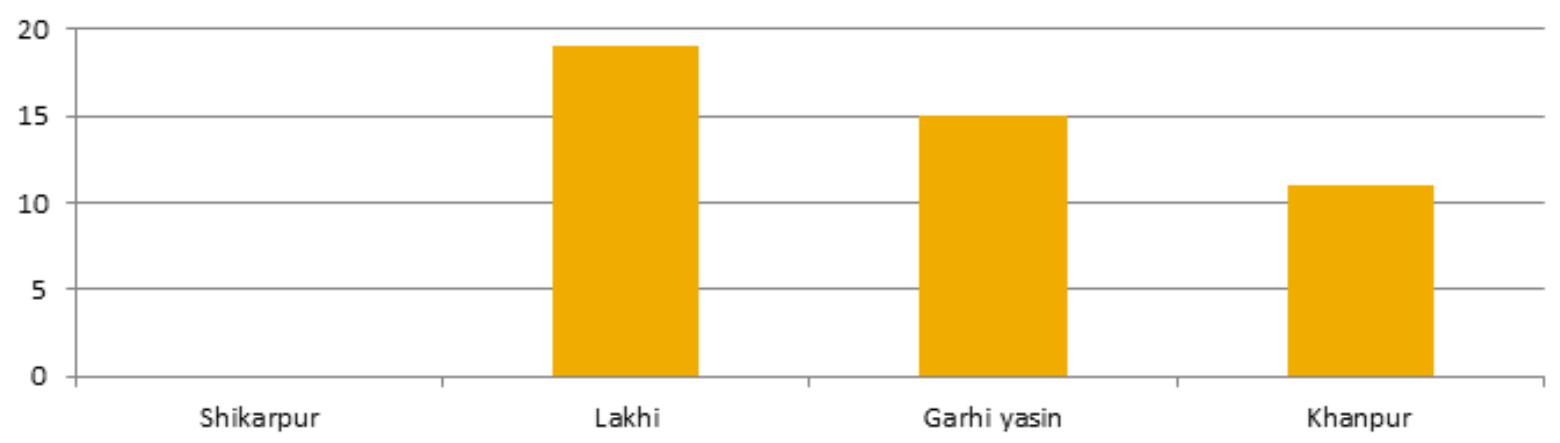

Number of Honor killing of women within 5 years

Figure 3: Honor killing of women Taluka wise within 5 years.

While in Garhi Yasin situation is also grave that within five years 15 women were killed in honor killing followed by Khanpur 11 women were killed in same years. Besides, in $75 \%$ incidents of honor, women are being killed and in only $25 \%$ men are charged to death sentence (Figures 3, 4 and 5).

\section{Honor killing of women by \%}

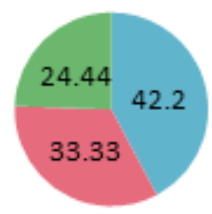

nakhi

- Garhi yasin

Khanpur

Figure 4: Honor killing of women by Taluka wise.

\section{Causes of Gender Inequality}

\section{Male child factor}

In the society of proposed area, male child is preferred over female child. Most of the families prefer to have male child rather than female child. Similarly, girls are often denied their fundamental rights such as education, food, health and marriage. As a result, girls are facing social and economic confrontations.

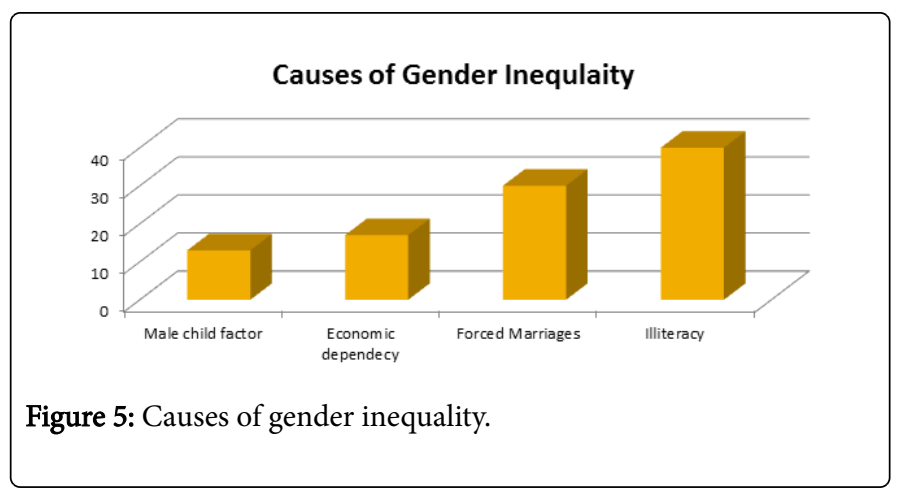


The most havoc social problem faced by woman in this society is honor killing. Society considers woman inferior to man and that's why, people don't hesitate to kill woman rather man in the name of honor killing (Figure 6).

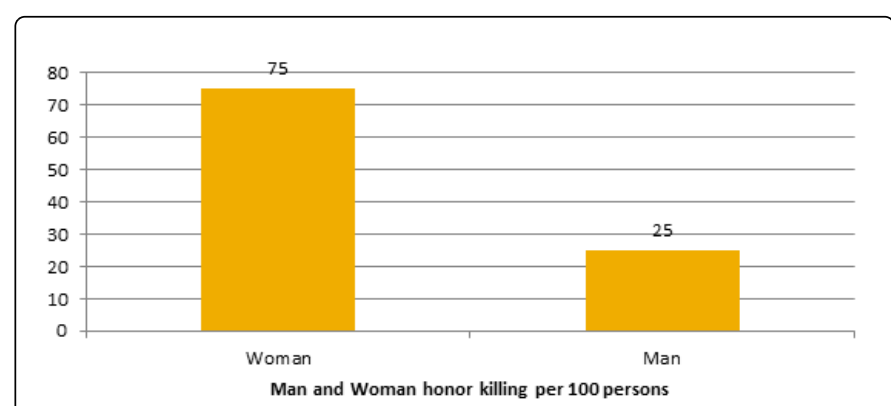

Figure 6: Gender wise honor killings per 100 persons.

\section{Economic dependency}

Women are totally dependent on sympathy of men. Women don't possess any right of ownership of any property. Even, women have no right to earn money for their livelihood. The expensive of basic necessities such as food, cloth and health are fulfilled by men. That's why; women are totally relied on sympathy of men. Owing to, weak financial position of women, they are vulnerable to become victim of honor killing. In the study area except Shikarpur town, out of 100 only 7 to 8 women are engaged in formal occupation, while 92 to 93 women are housewives or engaged in informal occupation such as livestock and agriculture. Moreover, $99 \%$ of the property is owned by men and only $1 \%$ ownership of property belongs to women in the study area. This economic weakness of women leads them to become victim of honor killing (Figure 7).

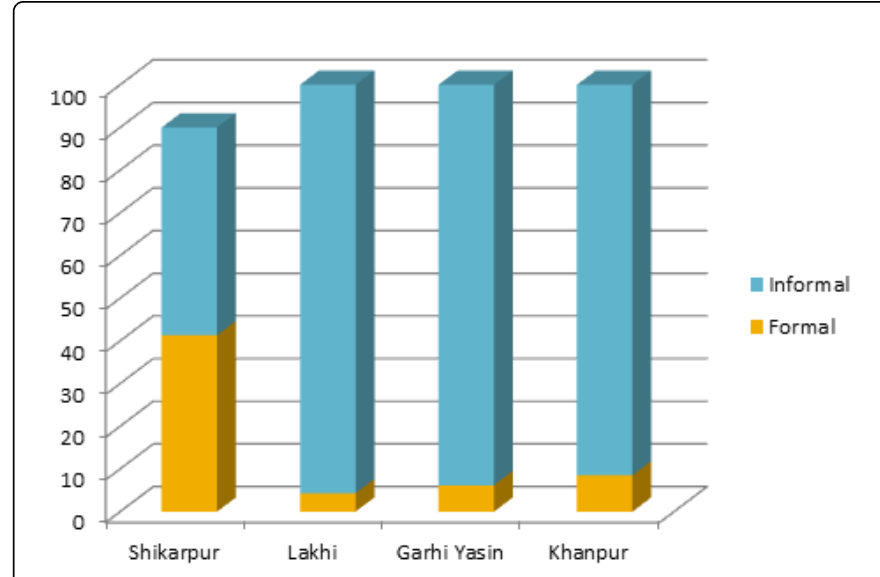

Figure 5: Occupation of women in formal and informal sectors.

\section{Forced marriages}

The study in the proposed area also revealed that women have no say in decision of her marriage. Even, woman cannot say a name of man to whom she wants to marry. If she does so, she will be killed in the name of honor killing. On the contrary, man has got full authority to choose his partner. He has right to decide his marriage and give his decision about his marriage, while, woman has no such right. The decision of her marriage is taken by her father, brother and uncle and their decision is final. Similarly, she is bound to obey their decision. If she declines, she will be killed in the name of honor killing. Our study revealed that 25 to $30 \%$ honor killing taking place due to this issue (Figure 8).

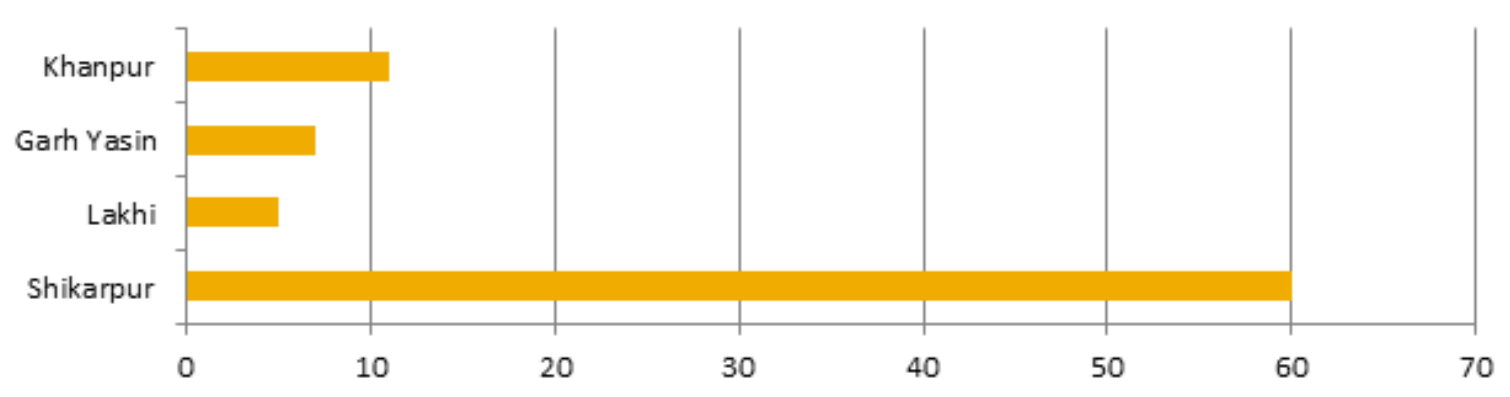

No of Women are asked for her marriage per 100 women

Figure 8: Married women who were asked for their marriage.

\section{Illiteracy}

Mass illiteracy among woman is also main cause of honor killing. Our study revealed that only 25.3 women are literate. While, $75 \%$ women are illiterate and among illiterate women about $60 \%$ don't know to write their names, besides, the illiteracy rate is found much higher in after 30 years old women, it stands at $90 \%$. Illiterate women don't know their rights that have been granted to them by law. As a result, most of the women are living in desperate condition. Owing to illiteracy, women are unable to raise their voice against heinous social crime, to reach court for justice and to fight against honor killing. As a result, women vulnerability to honor killing and other social crimes is much higher [4-7].

\section{Methodology}

The systematic stratified sample technique was used to collect data from entire district. The data were collected from both rural and urban areas. A total 15 villages selected from rural area of each taluka of district and 100 households of urban area respectively. Moreover, within each village 10 women aged between 20 and 30 years were 
interviewed. The types of questions were previously selected after studying the available literature in newspaper and directly participating in social activities in rural and urban areas. Then, questions were developed for obtaining final and effective data. Moreover, data were collected in local language, then, it was finalized, translated and interpreted in English language. Besides, fieldwork for obtaining data of Shikarpur district was done from March 15-2014 to January 25-2015.

\section{Results and Discussion}

Our research study reveals that gender inequality among men and women is the major cause of increasing honor killing in Shikarpur district. Gender inequality is observed in all spheres of life in the district. Honor killing has been increasing since couple of years in the district. Our study reveals that within 5 years 45 women are killed in the name of honor killing. Out of 45 women, 11 women are killed in Khanpur town, followed by 15 women in Garhi Yasin town and 19 women in Lakhi town respectively as mentioned in Figure 1. Moreover, Figure 3 depicts that more women are murdered in Lakhi town that account $42.2 \%$ of honor killing in the district. Besides, questions were asked for obtaining data about possible causes of gender inequality in the district that leads women honor killing.

Around 150 women of each town were asked for above mentioned question. Out of 150 women, $45 \%$ women believe that illiteracy is major cause, followed by $15 \%$ male child preference and $40 \%$ women believe that forced marriages and economic dependency are major factors that lead women honor killing in the district as mentioned in the Figure 6. This data reveal that maximum women believe that mass illiteracy among them is major factor that leads killing of women in the name of honor killing. Besides, Figure 4 shows that more women are murdered in honor killing though, both man and woman are equally responsible for an immoral act. Our study reveals that in $75 \%$ honor killing cases, women are being killed and in only $25 \%$ cases, men are being killed.

This is because of male child preference. People believe that female is inferior to male and this immoral perception justify the protection of man from killing and making woman vulnerable for killing in the name of honor killing. Moreover, economic dependency also believes to be one of the major causes of honor killing in the area. In Figure 7, it reveals that majority of the women are engaged in informal occupations and fewer number of women are engaged in formal occupations. As Figure 7 shows that most women in taulka lakhi are engaged in informal sector followed by Khanpur, Garhi Yasin and Shikarpur taulkas. Besides, Figure 8, shows women, who were asked consent for their marriage. It reveals that more women were asked in taulka Shikarpur, followed by Khanpur, Garhi Yasin and Khanpur.

\section{Recommendations}

- Female education must be encouraged throughout the district Shikarpur particularly in rural areas.
- Female training institutions should be established in each town of district that avail free training to young women.

- Loan should be provided to women as they can be sound economically.

- Awareness campaign must be held throughout district about rights and respect of women in the society.

- There should be an organization in the district that supports, help and address women during violence against them.

- There must be strong legal system that holds accountable to people who are involved in honor killing.

- Law and order forces must effectively work for protecting women in the area.

- Further research must be encouraged in the study area at government level.

\section{Conclusion}

Gender inequality is one of the major factors of raising indiscriminate behavior against women in Pakistan that leads to honor killing. In district Shikarpur, gender inequality dominantly exists everywhere ranging from social to political and from economic to domestic spheres of life. This gender based discrimination leads women to be victim of honor killing. Currently, drastic measurements are needed to protect the sanctity of women in the study area. The effective role of government, civil society, media and NGOs is strongly needed to address the raising trend of honor killing against women.

\section{References}

1. Hilde B, Nonja M, Petra S (2012) Two steps forward, one back: Combating eergere based violence, abandonment huwelijksdwangen verlating. Utrecht: Movisie/Flying team.

2. Anna K, Gokce Y (2009) Gender Islam and immigrant integration: boundary drawing on honor killing in the Netherlands and Germany. Ethnic and Racial Studies 32: 218-238.

3. Moira D, Phillips A (2008) Whose agenda is it? Abuses of women and abuses of culture in Britain. Ethnicities 8: 405-424.

4. Diane B (2007) Honor thy sister: selfhood, gender, and agency in Palestinian culture. Anthropological Quarterly 80: 737-775.

5. Aylin A (2003) The honour/shame complex revisited-violence against women in the migration. In: Phyllis C (Ed.), Are honor killings simply domestic violence. Middle East Quarterly.

6. Mehr K, Kapoor S, Cooraswamy R (2000) Domestic violence against women and girls. Innocenti Digest 6: 1-30.

7. Engle MS (2009) Human rights and gender violence: translating international law into local justice. University of Chicago Press. 